鼡とする科研 $\mathrm{T}_{3}$-Uptake (MAA) キットにつき基礎的 検討を行った結果，(1)同時再現性は，CV 2.0\%以下，約 半年間にわたる Lot 間のバラッキむ3.8\%以下と良好で あった．(2)incubationは，室温10分で充分である. (3)被 検血清 $25 \mu \mathrm{l}$ の半量法 assay で充分臨床に使え 2 倍の州 ンプル測定が可能となり経済的である。(4)各種臨佅例て お污測定成績は，正常值 $24.6 \sim 32.1 \%$ であるが機能低 下症の一部で重なり合いを譛めた。以上本法は，トリオ ソルブM值，SPAC index とも良好な相関を認め，血清 量が半量の $25 \mu l$ でよく短時閐に処理出来るととから今 後のルチン検査に有用之考えられる。

242. 市販 PTH RIA キットの比較検討ならびに $\mathrm{N}$ 末端 アッセイ系について

京都大学医学部附属病院 放射線部 ○高坂唯子・新保多加子・古松亘子 藤田 透・中島言子

PTH “栄研” および PTH-I ・ 125 (CIS) キットにつ いて若平の比較を行うと共に，自家標識による $\mathrm{N}$ 末端 PTH の測定結果について報告した。市販 キットは両者 共h(1-34) PTH とは全く交电反店を示さなかったが h(53-84) PTH とは, “栄研” で22.3\%, CIS で76.7\% の交文が認められた。両キットの表示単位はそれぞれ異 なっているが，その間には $\mathrm{Y}$ (栄研， $\mathrm{ng} / \mathrm{ml}$ ) $=0.210 \times$ (CIS, $\mathrm{mlU} / \mathrm{ml})+0.187$ の関係が得られ，理論的な換算 值とよく一致した成續であった。また，自家標識しよる N末端アッセ住（h(1-34） PTH) によるPTH の測定

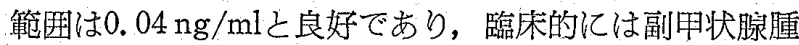
隍の局在診断や分泌負荷・抑制試験等の場合飞有用であ った.

243. 副甲状腺ホルモン (PTH)測定に関する検討 財団法人住友病院 アイソトープ室 ○本田・棇・金尾啓右・小川 正

C 端 PTH：RD24抗体を用いた自家測定系，ICL拉よ びCIS キットの 3 者について検討した．感度，精度，再 現性，回收率は，光れぞれ良好な成績であった。 1-34b PTH については，自家測定䒺で一部交叉性を認めた。副 甲状腺煰，腎不全など PTH 高値血清の希粎曲線は各標 準曲線と良く平行した。

$\mathrm{N}$ 端 PTH：同一条件の下で NLé8,18よりも NLe ${ }^{8,18}$, $\mathrm{Tyr}^{34}$ の抗体分結合率は良い。

結語：C端 PTH の測定が一般的ではあるが，生物学 的活性を有するN 端PTH の測定法についても言及した。

244. Amerlex $\mathrm{T}_{4}$ RIA キットの使用経験 北海道大学医学部附属病院放射線部
○鈴木幸太郎・表 英彦 勝浦秀則 · 村松祝子 放射線科 古館正従

甲状腺ホルモン $\mathrm{T}_{4}$ 測定用りアキットAmerlex $\mathrm{T}_{4}$ リ アキットを使用する機会を得たので報告する。本法は， $\mathrm{T}_{4}$ の抗体をラテックス粒子 $(1 \mu)$ にコーティングし固 相化したものでincubation は室温で45分である. Incubation 温度, 時間による影響は 3 濃度の血清について行 っだ結果， $20^{\circ} \mathrm{C} \sim 40^{\circ} \mathrm{C} ， 30 \sim 60$ 分でほぼ一定の值が得ら れ原法通りで良りと思われる. inter assay.及び intra assay 共飞 CV 2〜8\% と良认結果を得な. $\mathrm{T}_{4} \mathrm{RIA} \mathrm{KIT}$ IIとの相関は $\gamma=0.975$ と良く又回収率試験，稀噃試 験 の結果も良好であった。本法は各種試験の結果も良好で ピペッティング操作が少なく，血清も25 从1 と少量です む事から蹊床的に有用な甲状腺機能検查法である.

\section{Amerlex $\mathrm{T}_{3}$ リアキットの使用経験} 北海道大学医学部附属病院放射線部 ○表 英彦・勝浦秀則 鈴木幸太郎・村松祝子 司 放射線科 古館正彷

抗体をラテックス（值径約 $1 \mu$ ) にコーディングした 固相法による血清中 $T_{3}$ 測定用キット，Amerlex $T_{3}$ リア キットを使用する機会を得，いくつかの基礎的な検討を 行ったので報告した.

インキュベーション温度，時間については， $27^{\circ} \mathrm{C} \sim 47$ ${ }^{\circ} \mathrm{C}, 20 \sim 100$ 分間では, 3 種類の濃度の血清共大きな变化 は見られなかうた. Inter-assay, Intra-assayは，CV 3.0〜9.26\%, CV 4.8〜12.8\%となった. またT

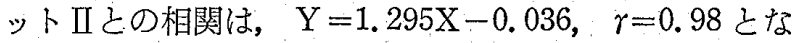
り非常に良好な相関が得られた，その他，回収率試験， 稀釈試験等も良好な結果となった。本キットは，血清量 が少なく，操作方法も簡単であり，臨床上有用なキット である。

246. 小児期の甲状腺機能検查 $\left(\mathrm{T}_{3} \mathrm{RSU}, \mathrm{T}_{3}, \mathrm{~T}_{4}, \mathrm{TSH}_{4}\right.$ Uptake) について 神奈川県立とども医療センター放射線科 ○藤生英夫 ·清水 敦 中川敏夫 : 梅津幹夫

[目的]甲状腺機能検查の方法は種々あるが，今回我 々は, 甲状腺ヨード摄取率検査を行った患児について, $\mathrm{T}_{3}-\mathrm{RSU}, \mathrm{T}_{3}, \mathrm{~T}_{4}, \mathrm{TSH}$ について分析をおてなった。

[方法及び結果].約 9 年間における523例で，その年龄

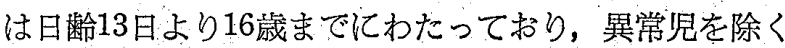
と；その正常範囲は， $\mathrm{T}_{3}$-RSUで $30 \pm 2 \% ， \mathrm{~T}_{3} 1.76 \pm$ 